\section{IBM PENYULINGAN MINYAK KAYU PUTIH DAN BRIKET ARANG DI DESA DELO DAN RAEKORE}

\author{
Dedy Nataniel Ully*, Bernadus \\ Wuwur
}

Teknik Mesin, Politeknik Negeri Kupang

\author{
Article history \\ Received : 27-01-2018 \\ Revised : 25-05-2018 \\ Accepted : 28-05-2018
}

\section{*Corresponding author}

Dedy Nataniel Ully

Email : dedy_ully@yahoo.com

\begin{abstract}
Abstraksi
Masyarakat Desa Delo dan Raekore memiliki usaha penyulingan minyak kayu putih yang dilakukan secara tradisional yaitu dengan cara merebus daun kayu putih untuk diambil minyaknya sebagai minyak aroma terapi. Minyak kayu putih yang dihasilkan cukup baik, hanya saja proses penyulingannya cukup lama yaitu 5 sampai 6 jam sehingga membutuhkan bahan kayu bakar yang cukup banyak. Sementara ketersediaan kayu bakar di hutan saat ini cukup sulit, sehingga masyarakat tak jarang menebang pohon di hutan. Maka perlu solusi untuk mengubah cara perebusan dengan metode kukus dan menggunakan bahan bakar briket arang yang terbuat dari sampah berupa tempurung kelapa, karena memiliki nilai kalor yang lebih tinggi dari pada tempurung yang dibakar secara langsung. Produksi minyak kayu putih yang dihasilkan dengan cara penyulingan tradisional, berkisar antara 2 sampai 3 botol bir ( 1 botol bir $=350 \mathrm{ml}$ ) per hari, sehingga melalui kegiatan IBM ini dapat menerapkan produk teknologi tepat guna yaitu instalasi penyulingan minyak kayu putih dengan metode kukus dan penggunaan bahan bakar briket. Wadah kukus yang dihasilkan memiliki volume 160 liter sedangkan alat pencetak briket arang mampu mencetak 8 briket arang dalam sekali cetak. Penggunaan instalasi penyulingan dengan metode kukus dan bahan bakar briket arang dapat meningkatkan kapasitas produksi minyak kayu putih sehingga dapat mendorong peningkatan ekonomi masyarakat desa Delo dan Raekore. Instalasi penyulingan minyak kayu putih memiliki kapasitas produksi 4 sampai 5 botol bir ( 1 botol bir $=350$ $\mathrm{ml}$ ) per hari dan alat pencetak briket arang memiliki kapasitas produksi 8 briket arang sekali cetak.
\end{abstract}

Kata Kunci: Penyulingan, Metode Kukus, Briket Arang

\begin{abstract}
Villagers of Delo and Raekore have a traditional eucalyptus refining business by boiling the eucalyptus leaves for aromatic oils. Eucalyptus oil produced quite well, it's just a long distillation process that is 5 to 6 hours so it requires a lot of wood. While the availability of firewood in the forest is currently quite difficult, so people often cut down trees in the forest. So need to find a solution by changing the way of boiling by steam method and using charcoal fuel made from coconut shell, because it has a higher calorific value than the shell is burned directly. Traditional refined eucalyptus oil products, ranging from 2 to 3 beer bottles (1 bottle of beer $=350 \mathrm{ml}$ ) per day, so that through the activities of IbM can apply the appropriate technology products that is the installation of wood crude oil refinery by steam method and the using of briquette fuel. The steamed container produced has a volume of 160 liters while the charcoal briquette printing device is capable of printing 8 charcoal briquettes in one print. The using of refinery installations by steam method and charcoal charcoal fuel, can increase the production capacity of eucalyptus oil to encourage economic improvement of Delo and Raekore villagers. The eucalyptus refining oil refinery has a production capacity of 4 to 5 bottles of beer ( 1 bottle of beer $=$ $350 \mathrm{ml}$ ) per day and charcoal briquette presses have a production capacity of 8 charcoal briquettes.
\end{abstract}

Keywords: Distillation, Steamed Method, Charcoal Briquette 


\section{PENDAHULUAN}

Masyarakat Desa Delo dan Raekore umumnya memiliki mata pencaharian sebagai petani di ladang maupun di sawah. Kegiatan bertani di ladang maupun di sawah berlangsung hanya sekitar 4 sampai 5 bulan saja, itupun tidak dilakukan setiap hari. Sehingga pada musim kemarau masyarakat beralih ke kegiatan lain seperti memelihara ternak, menyadap enau dan ada juga yang membentuk kelompok usaha penyulingan minyak kayu putih, guna menambah penghasilan mereka (sumber : Hasil Survei). Diantara beberapa kegiatan yang dilakukan masyarakat di atas, ada satu kegiatan yang sangat menguntungkan secara ekonomi yaitu penyulingan minyak kayu putih, karena ketersediaan bahan baku berupa daun kayu putih yang sangat melimpah dan tersebar di beberapa wilayah dengan luas total 7 sampai 8 hektar. Hanya saja metode penyulingan minyak kayu putih di kedua desa ini masih menggunakan cara penyulingan tradisional yaitu dengan metode perebusan dengan menggunakan kayu bakar, sehingga jika kegiatan penyulingan ini berlangsung lama dapat merusak lingkungan atau alam.

Hal ini terjadi karena masyarakat menebang pohon di hutan dalam jumlah yang banyak untuk keperluan penyulingan minyak kayu putih dan juga untuk keperluan memasak di dapur. Kebiasaan ini dapat memicu terjadinya berbagai bencana alam seperti banjir, tanah longsor,karena hutan menjadi gundul, kerusakan ekosistem di sekitar hutan dan lain sebagainya. Dengan adanya potensi daun kayu putih yang melimpah, maka usaha penyulingan minyak kayu putih yang masih dilakukan secara tradisional ini cukup menjanjikan. Meskipun masih menggunakan penyulingan tradisional yang rata-rata hasilnya berkisar antara 2 sampai 3 botol bir (1 botol bir $=350 \mathrm{ml}$ ) dalam sehari (sumber: kelompok usaha). Hal ini tentu sangat membantu masyarakat di kedua desa untuk tetap produktif di musim kemarau.

Jika satu botol minyak kayu putih dihargai Rp 250.000 maka petani dapat memperoleh vang kurang lebih Rp 500.000 sampai Rp 750.000 per hari. Dengan beranggotakan 4 orang maka setiap orang dapat memperoleh vang sebesar 125.000 sampai Rp. 187.500 per hari. Berdasarkan uraian di atas maka dapat disimpulkan bahwa usaha penyulingan minyak kayu putih secara tradisional ini sangat potensial untuk dibina dan dikembangkan sehingga dapat meningkatkan taraf hidup masyarakat pedesaan.
Penelitian tentang penyulingan minyak kayu putih sudah banyak dilakukan oleh beberapa peneliti terdahulu yakni tentang isolasi, identifikasi dan pemurnian senyawa 1,8 sineol minyak kayu kutih (malaleuca leucadendron). Penelitian ini dilakukan dengan metode eksperimental di lapangan. Hasil penelitian menunjukkan bahwa rendemen minyak kayu putih tertinggi diperoleh dengan menggunakan metoda distilasi kukus dengan rendemen sebesar $2,5 \%$. Sedangkan kandungan senyawa 1,8 sineol yang terdapat pada minyak kayu putih hasil distilasi kukus, rebus dan uap memenuhi persyaratan SNI (Helfiansah, Saatrohamidjojo dan Riyanto, 2013).

Penelitian selanjutnya dilakukan tentang kualitas minyak kayu putih hasil penyulingan secara tradisional di Namlea. Penelitian dilakukan dengan metode eksperimental di lapangan yaitu dengan melakukan pengamatan langsung. Dari penelitian ini, didapat kesimpulan sebagai berikut; besar kalor rata-rata untuk memanaskan ketel pada hari pertama 1371,69 Kkal dan hari kedua 1499,54 Kkal. Nilai energi yang begitu besar memberikan hasil penyulingan yang sangat baik, yang didapatkan dengan waktu penyulingan selama 8 jam dengan tanpa adanya perlakuan terhadap bahan baku daun kayu putih. Hasil analisis laboratorium menunjukan kualitas minyak kayu putih untuk penyulingan secara tradisional dan olahan pabrik yang cukup populer digunakan dikalangan masyarakat menunjukan perbedaan yang cukup signifikan (Paty, 2014).

Penelitian selanjutnya dilakukan tentang destilasi daun kayu putih dengan variasi tekanan operasi dan kekeringan bahan untuk mengoptimalkan kadar sineol dalam minyak kayu putih. Tujuan penelitian ini untuk mengetahui rendemen dan kadar sineol dari setiap perlakuan bahan yaitu daun kayu putih segar, layu,dan kering dengan tekanan operasi 0,$5 ; 1 ; 1,5 ; 2$ dan $2,5 \mathrm{~kg} / \mathrm{cm} 2$. Penelitian ini dilakukan dengan metode eksperimental di laboratorium. Dari hasil penelitian diperoleh kualitas minyak kayu putih terbaik pada variable daun kering dengan tekanan $2 \mathrm{~kg} / \mathrm{cm} 2$. Rendemen 0,638 \% dan kadar sineol 91,50\% (Muyassaroh, 2016).

Penyulingan minyak kayu putih membutuhkan kayu bakar untuk pembakaran. Selama ini warga desa menggunakan kayu bakar yang diperoleh dari hutan. Dengan potensi penyulingan minyak kayu putih yang bagus maka kondisi ini harus diperhatikan agar tidak merusak hutan. Kebutuhan bahan bakar penyulingan memerlukan alternatif bahan bakar sehingga kegiatan penyulingan bisa berjalan tanpa merusak ekosistem hutan. 
Kegiatan IBM ini membuat rancangan penyulingan minyak kayu putih yang lebih modern sehingga mampu meningkatkan produksi minyak kayu putih warga. Selain itu dibuat alat pencetak briket arang sebagai bahan baku alternatif warga selain kayu bakar.

\section{TAHAPAN PELAKSANAAN}

\section{Identifikasi Permasalahan Mitra}

Hasil observasi lapangan yang dilakukan diketahui bahwa mitra memiliki permasalahan yang sangat serius berkaitan dengan :

1. Mitra memiliki instalasi penyulingan minyak kayu putih yang kurang memadai, karena metodenya masih sangat sederhana yaitu metode perebusan sehingga kurang maksimal dalam menghasilkan produksi minyak kayu putih.

2. Kondisi tungku masak garam masih bersifat terbuka sehingga operator mengalami batuk dan sesak napas akibat asap.

3. Modal,pengetahuan, dan ketrampilan mitra yang terbatas dalam hal pemanfaatan limbah tempurung kelapa untuk diolah menjadi briket arang yang memiliki nilai kalor yang lebih tinggi.

4. Ketersediaan bahan bakar (kayu bakar) di hutan yang semakin menipis.

Untuk itu perlu kiranya usaha ini dibina dan dikembangkan melalui penerapan teknologi tepat guna (peralatan penyulingan dengan metode kukus) dan menggunakan bahan bakar alternatif berupa briket arang dari tempurung dan sabut kelapa untuk dijadikan bahan bakar padat sehingga menghasilkan energi panas untuk mengukus daun kayu putih.

\section{Metode Pendekatan Yang Ditawarkan}

Metode pendekatan yang ditawarkan untuk mendukung keberhasilan kegiatan ini adalah melalui pelatihan dengan beberapa metode antara lain ceramah, diskusi atau tanya jawab dan demonstrasi,

1. Metode ceramah : digunakan untuk menyampaikan informasi dan pengetahuan dasar tentang penyulingan minyak kayu putih dengan metode yang lebih baik yaitu metode kukus dan pemanfaatan limbah berupa tempurung dan sabut kelapa untuk dijadikan bahan bakar alternative.

2. Metode diskusi atau tanya jawab yaitu untuk berdiskusi tentang hal-hal yang belum dipahami dan yang akan dibuat terutama tentang proses penyulingan dengan metode kukus dan pembuatan briket arang.
3. Metode demonstrasi : digunakan untuk mendemonstrasikan bagaimana membuat instalasi penyulingan dengan metode kukus dan proses pembuatan alat pencetak briket arang sesuai dengan desain atau gambar kerja yang sudah disiapkan.

\section{Penetapan Target Luaran}

Target luaran yang direncanakan bersama mitra adalah berupa 2 buah teknologi tepat guna yaitu 2 buah instalasi penyulingan minyak kayu putih dan alat pencetak briket arang. Instalasi penyulingan minyak kayu putih terbuat dari bahan anti karat yaitu stainless steel, sehingga tahan terdapat korosi dan juga sangat baik dalam proses perpindahan panas dari tungku ke bagian atau wadah penyulingan, sehingga dapat meningkatkan kapasitas produksi.

\section{Partisipasi Mitra dalam Melaksanakan Program}

Adapun pratisipasi yang harus dilakukan mitra dalam program ini adalah :

1. Turut serta dalam memberikan informasi yang digunakan untuk seleksi konsep dalam merancang dan membuat peralatan serta menjalankan usahanya.

2. Aktif mendiskusikan solusi perbaikan sarana atau peralatan penyulingan minyak kayu putih.

3. Aktif dalam kegiatan pelatihan aplikasi operasional pemakaian peralatan penyulingan minyak kayu putih yang dihasilkan dalam kegiatan ini.

4. Aktif dalam kegiatan pelatihan aplikasioperasional pemakaian mesin penggiling arang yang dihasilkan dalam kegiatan ini.

5. Aktif dalam kegiatan pelatihan operasional aplikasi pemakaian alat pencetak briket arang yang dihasilkan dalam kegiatan ini.

6. Aktif dalam mengikuti pelatihan tentang teknik perawatan dan perbaikan peralatan penyulingan minyak kayu putih dan mesin penggiling arang serta alat pencetak briket arang.

\section{Prosedur Pelaksanaan}

Untuk menyelesaikan dan menghasilkan target luaran yang sudah disepakati bersama mitra maka perlu prosedur pelaksanaan kegiatan dilakukan sebagai berikut :

1. Perancangan fungsional maupun konstruksional.

2. Pembuatan komponen serta perakitan alat yang dibuat.

3. Melakukan uji fungsi dari instalasi penyulingan minyak kayu putih dan alat pencetak briket 
arang serta melakukan penyempurnaan terhadap bagian-bagian yang belum maksimal.

4. Pelatihan terhadap mitra tentang cara mengoperasikan dan merawat teknologi tepat guna ini.

\section{Evaluasi Pelaksanaan Program dan Kelanjutan Program Setelah Kegiatan IbM Selesai Dilaksanakan}

Adapun uraian tentang eveluasi pelaksanaan program IbM, sehingga program ini dapat berhasil sebagai berikut :

1. Melakukan evaluasi terhadap proses karbonisasi arang, pembuatan adonan arang, pencetakan briket arang, penjemuran briket arang dan evaluasi penggunaan briket arang.

2. Melakukan evaluasi terhadap efektifitas proses penyulingan minyak kayu putih dengan metode kukus dan menggunakan briket arang sebagai bahan bakar.

\section{PEMBAHASAN}

Untuk pembuatan instalasi penyulingan berupa wadah kukus dilakukan di Laboratorium Perawatan \& Perbaikan Jurusan Teknik Mesin Politeknik Negeri Kupang. Wadah kukus ini terbuat dari stainless steel sehingga tidak terjadi korosi atau karat dan sangat baik dalam hal perpindahan panas sehingga dapat menghemat pemakaian bahan bakar. Wadah kukus dapat dilihat pada gambar 1, 2 dan 3 di bawah ini :

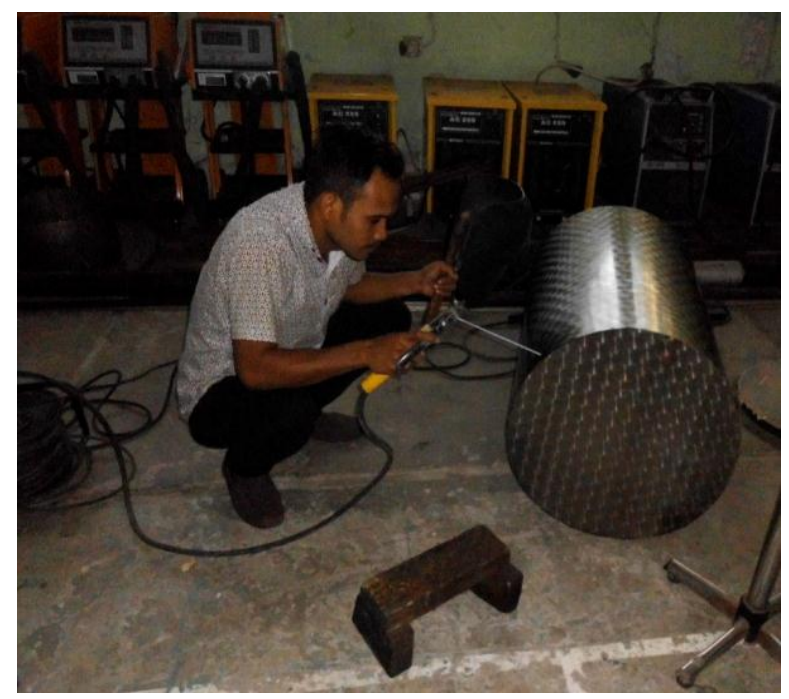

Gambar 1. Proses Pengelasan Wadah Kukus

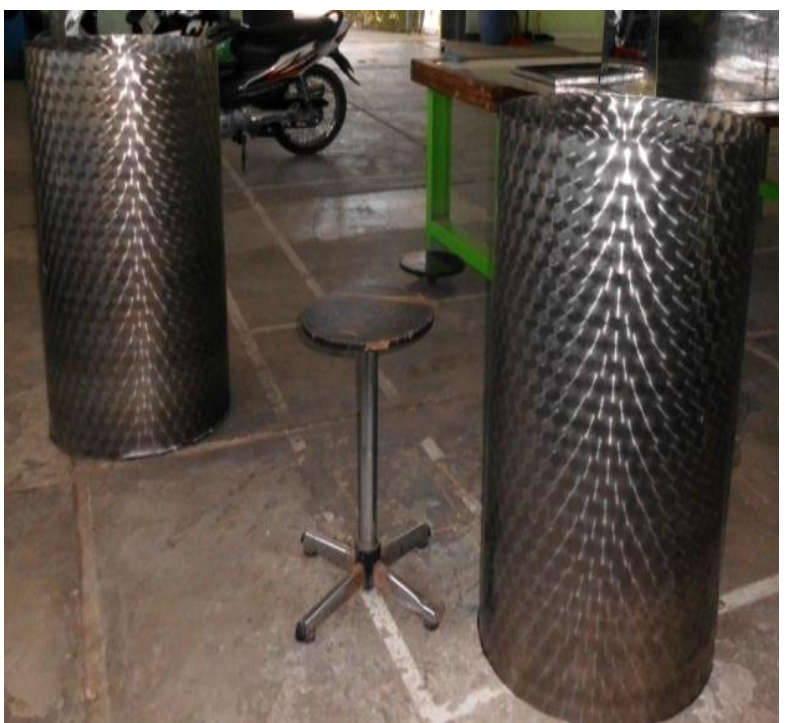

Gambar 2. Wadah Kukus setelah Dilas

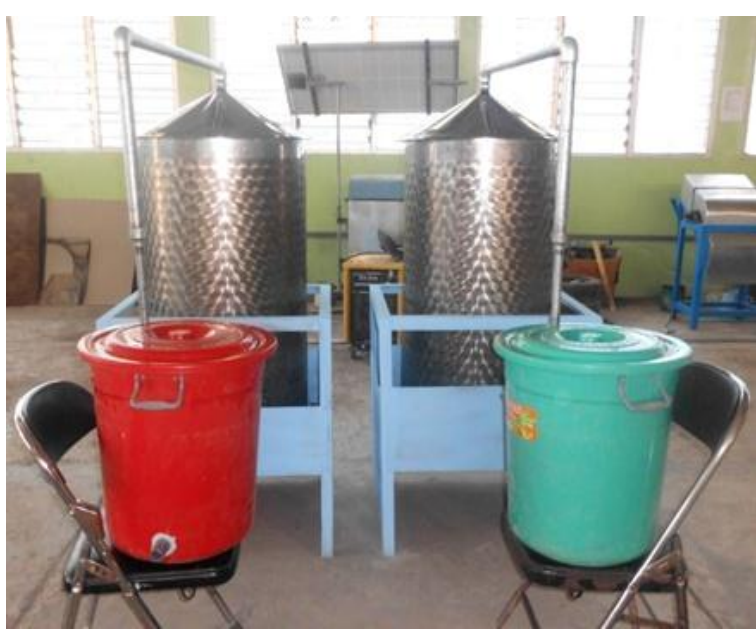

Gambar 3. Instalasi Penyulingan Minyak Kayu Putih

Sementara pembuatan alat pencetak briket arang dilakukan di Laboratorium Teknologi Mekanik karena peralatan pendukung yang tersedia dan lebih lengkap, seperti mesin potong plat $5 \mathrm{~mm}$ dan mesin bor radial. Alat pencetak briket arang ini dapat melakukan pencetakan 8 buah briket arang dalam sekali cetak, sehingga tidak membutuhkan waktu yang lama dalam proses pencetakan. Selanjutnya briket arang dijemur beberapa hari sebelum dipakai. Gambar alat pencetak briket arang dapat dilihat pada gambar 4 . 


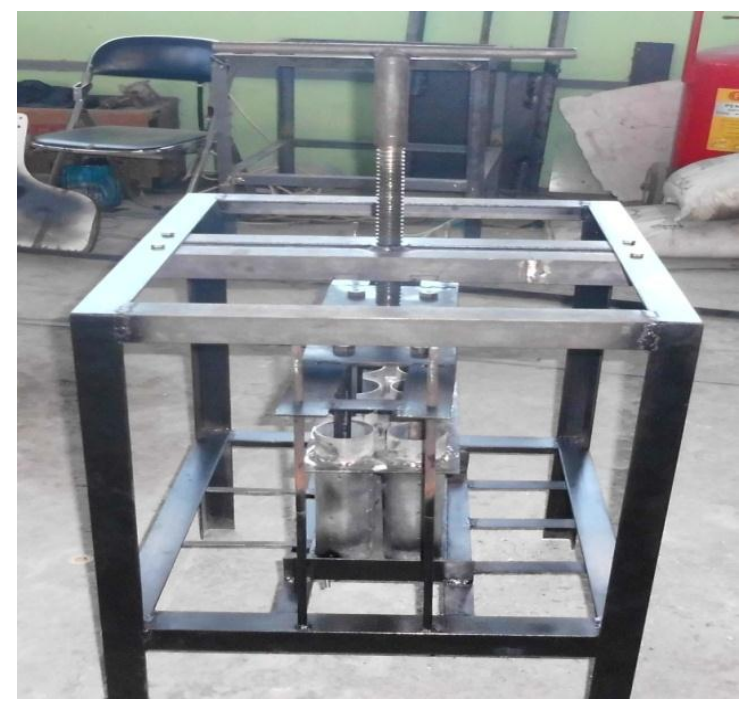

Gambar 4. Alat Pencetak Briket Arang

Adanya teknologi tepat guna ini dapat meningkatkan kapasitas produksi minyak kayu putih dan mengurangi ketergantungan terhadap kayu bakar sebagai bahan bakar utama dalam kegiatan ini. Briket arang merupakan solusi terhadap kesulitan yang dialami masyarakat di kedua desa dalam mendapatkan kayu bakar di hutan.

Penggunaan instalasi penyulingan dengan metode kukus dan bahan bakar briket arang, dapat meningkatkan kapasitas produksi minyak kayu putih sehingga dapat mendorong peningkatan ekonomi masyarakat desa Delo dan Raekore. Intalasi penyulingan minyak kayu putih memiliki kapasitas produksi 4 sampai 5 botol bir (1 botol bir $=350 \mathrm{ml}$ ) per hari dan alat pencetak briket arang memiliki kapasitas produksi 8 briket arang sekali cetak.

\section{KESIMPULAN}

Kegiatan Iptek bagi Masyarakat (IbM) khususnya mitra penyulingan minyak kayu putih di desa Delo dan Raekore menghasilkan 3 (tiga) buah produk teknologi yang dapat diterapkan.Ini akan sangat memberikan manfaat bagi masyarakat desa Delo dan Raekore dalam meningkatkan produksi minyak kayu putih dilihat dari segi waktu, tenaga, serta biaya operasional. Intalasi penyulingan minyak kayu putih memiliki kapasitas produksi 4 sampai 5 botol bir (1 botol bir $=350 \mathrm{ml}$ ) per hari dan alat pencetak briket arang memiliki kapasitas produksi 8 briket arang sekali cetak. Kesulitan yang dihadapi dalam pembuatan produk teknologi ini yaitu pada proses pengelasan wadah kukus yang menggunakan kawat las stainless steel karena pada proses ini dibutuhkan ahli las yang terampil.

\section{PUSTAKA}

Helfiansah. R; Saatrohamidjojo. H; Riyanto. 2013. Isolasi, Identifikasi dan Pemurnian Senyawa 1,8 Sineol Minyak Kayu Putih (Malaleuca leucadendron). ASEAN Journal of Systems Engineering, 1(1): 19-24

Paty. J. D. 2014. Kualitas Minyak Kayu Putih Hasil Penyulingan Secara Tradisional Di Namlea. Seminar Nasional Basic Science VI F-MIPA UNPATTI.

Muyassaroh. 2016. Destilasi Daun Kayu Putih Dengan Variasi Tekanan Operasi dan Kekeringan Bahan Untuk Mengoptimalkan Kadar Sineol Dalam Minyak Kayu Putih. Jurnal Teknik Kimia 10(2): 36-42 